\title{
Argument structure constructions among German prepositional objects
}

\section{Rostila, Jouni Pekka}

De Gruyter Mouton

2018-07

Rostila , J P 2018 , Argument structure constructions among German prepositional objects . in H C Boas \& A Ziem (eds), Constructional Approaches to Syntactic Structures in German . Trends in Linguistics. Studies and Monographs [TiLSM] , no. 322 , De Gruyter Mouton , Berlin , pp. 406-446 . https://doi.org/10.1515/9783110457155-011

http://hdl.handle.net/10138/310610

https://doi.org/10.1515/9783110457155-011

unspecified

acceptedVersion

Downloaded from Helda, University of Helsinki institutional repository.

This is an electronic reprint of the original article.

This reprint may differ from the original in pagination and typographic detail.

Please cite the original version. 


\title{
Argument structure constructions among German prepositional objects
}

Jouni Rostila (University of Helsinki)

\begin{abstract}
Object markers in the form of prepositions such as auf (e.g. with warten 'wait') and an (e.g. with zweifeln 'doubt') in German have hitherto mostly been described as lexical idiosyncrasies of the predicate head they accompany. However, there seem to be reasons to assume that some of them have turned into productive templates whose choice displays semantic regularities. This paper argues that such productive prepositions of prepositional objects in fact constitute argument structure constructions whose sole formal exponent is the preposition in question. What is more, the emergence of such productivity can be viewed as a grammaticalization process. The proposal has repercussions for the discussion of whether argument structure constructions can be considered products of grammaticalization, for the description of similar prepositional structures in other languages, and for the catego rization of primary adpositions into classes like lexical vs. grammatical/functional.
\end{abstract}

\section{Introduction}

Prepositional objects $(P O)$ are in German linguistics understood to be structures such as (1), where a lexical head (boldface) selects a certain preposition as its object/complement marker, which in turn usually governs the accusative or the dative case:

(1) a. Er wartet auf den Zug.

he waits on the.ACC train

'He waits/is waiting for the train.

b. Ich zweifle an seiner Ehrlichkeit.

I doubt at.DAT his.DAT honesty

'I doubt his honesty.'

c. Er ist stolz auf ihre Leistung.

he is proud on her.ACC achievement

'He is proud of her achievement.'

d. Seine Abhängigkeit vom Sport macht ihn kaputt.

his dependence from.dat sports makes him broken

'His dependence on sports destroys/is destroying him.'

e. Seine Dankbarkeit für unsere Hilfe war offensichtlich. his thankfulness for our.ACC help was obvious

'His thankfulness for our help was obvious.'

f. Wir haben uns mit ihnen kurz unterhalten.

we have ourselves with them.DAT short entertained

'We talked briefly with them.' 
g. Er hat für die neue Partei gestimmt. ${ }^{1}$
he has for the.ACC new party voted
'He voted for the new party.'

Since the choice of preposition in such structures is mostly lexically determined by a verb or other predicative head, ${ }^{2}$ the prepositions of prepositional objects can be considered analytic counterparts of lexical/inherent cases (see Rostila 2007: 111-114; 205-211 for discussion). Accordingly, such uses of prepositions have hitherto mostly been described as lexical idiosyncrasies of the heads they accompany. ${ }^{3}$ In the seemingly fairly rare cases where semantic regularities governing the choice of the preposition can be discerned, these have been interpreted as being due to remains of the original lexical semantics of the preposition in question (cf. Dürscheid 1999: 12; Zifonun et al. 1997: 1368). In Rostila (2002; 2004; 2005; 2007; 2014), I have argued for a revision of this view, proposing that some prepositions of prepositional objects in fact constitute independently meaningful productive patterns that can be described as a(rgument structure)-constructions in the sense of Goldberg (1995). Their independent meaning contribution is not solely a function of their original lexical semantics, but derives to a large part from a process in which formerly lexically selected prepositions - the type that probably constitute the bulk of prepositions of prepositional objects - gain independence from the verbs and other predicate heads governing them, and, in a sense, take over some of the semantics of their former governing heads. As I have argued before and will show below, this process can plausibly be analyzed as a process of grammaticalization. If this view is viable, it has far-reaching consequences: it suggests that a-constructions in general might be products of grammaticalization, and that abstract senses of local prepositions might sometimes stem from verbs and other predicate heads which have lexically governed/selected them for a certain period.

\footnotetext{
${ }^{1}$ For the sake of clarity, and in the interest of readers less familiar with German, I have frequently made use of simple constructed or dictionary examples when the argument concerns basic properties of prepositional objects and clear-cut grammaticality judgments. More complex authentic examples from the web and literary sources (see the list of such cases at the end of the paper) are used when suitably simple cases could be found, or to illustrate phenomena of border-line character that might be worth a more thorough empirical study. In all examples, glossing (especially in terms of grammatical categories) only extends to the parts relevant for the discussion. To avoid unnecessary details, no segmentation of grammatical morphemes is undertaken; thus for instance auf den Zug in (1a) is glossed 'on the. ACC train', although an analysis like auf de-n Zug 'on the-ACC train' would be more correct.

${ }^{2}$ Critical comments by a reviewer reveal that the concept of lexical selection I employ is a potential source of misunderstanding. The purport of this concept is that a lexical head selects (or determines/governs) a certain other lexical head (or other element, e.g. case morpheme) to accompany it, not a semantically defined class of accompanying heads. Under this view, verbs like e.g. locational sein 'be', liegen 'lay', or sich befinden 'be situated' do not lexically select the $\mathrm{P}(\mathrm{P}) \mathrm{s}$ that complement them. The reason for this is that they do not select an individual lexical head, but a whole semantically defined class of these, which even extends to locational adverbials (cf. e.g. sich im Zug 'in the train'/auf dem Tisch 'on the table'/unter dem Tisch 'under the table'/um die Ecke 'around the corner'/dort 'there' befinden). By contrast, my concept of lexical selection only covers cases where an individual head selects another individual lexical head, or a case morpheme. The justification for such a narrow concept of lexical selection is to be seen in the circumstance that it can explain the semantic bleaching of the selected elements: they become de facto parts of the sign doing the selecting, see below sections 2.1 and 3.2 for discussion. As regards cases like sich im Zug/um die Ecke befinden, I would not in fact consider them cases of lexical selection at all (doing so would amount to assuming Chomskyan s-selection; cf. Chomsky 1986: 86). Since they are instances of a productive pattern, they should be seen as cases of a-constructions selecting semantically adequate fillers for both a verb slot and a slot for a locational complement; see (16) below for a schematic representation.

${ }^{3}$ Even work as recent as Müller and Wechsler (2014: 41) proposes such idiosyncratic selection of preposition for warten $+a u f$ (cf. (1a)), a prime example for a prepositional object where the choice of preposition can be accounted for in terms of the argument structure construction approach advocated in this paper.
} 
The structure of the paper is as follows: in section 2, I recapitulate and further develop arguments from my earlier work for the view that some prepositions of prepositional objects, henceforth $P O-P S$, above all prospective auf (as in (1a)), can be deemed manifestations of a-constructions. In section 3, I will argue for regarding productive PO-Ps, and in fact all a-constructions, as products of grammaticalization. The stances of Schøsler (2007) and Noël (2007a,b) on this issue will prove instrumental to this argumentation by showing where informed and influential views require revision. In addition, I consider the question of whether insights into the development of verb islands into aconstructions in child language can shed light on the diachronic emergence of productive PO-Ps from ordinary PO structures, which at least very closely resemble verb islands. Finally, in section 4, I sketch the repercussions of my proposal for the classification of primary adpositions and its prospects for research into the emergence of abstract senses of primary local adpositions.

\section{Productive PO-Ps as a-constructions}

\subsection{Evidence for a-constructions among PO-Ps}

The bulk of PO-Ps in German are probably lexically governed by individual heads and hence adequately described in the traditional way, i.e. as lexical idiosyncrasies of predicate heads. As I have argued in more detail in Rostila (2002; 2004; 2007), such PO-Ps are essentially without independent semantics, since they do not commute in the structuralist sense, i.e. cannot be selected on their own, but only along with the head governing them. In other words, they do not constitute independent signs, but parts of larger signs. Examples of PO-Ps of this type can be seen in (1b-g). To be sure, some PO-Ps of this class do seem to display an independent meaning contribution: e.g. in (1f), mit denotes an accompanying relation, and in (1g), für displays a meaning like that of English for in for or against, or vote for. However, in such cases the possibility of assigning the preposition an independent semantics is probably due to the lexical semantics that the preposition had before becoming lexically governed. The former independent semantics still shows, since the preposition in question has not been part of another sign for long.

Recently "recruited" PO-Ps like those in (1f-g) thus accord with the traditional view that any discernible semantics of PO-Ps is due to their original lexical semantics (cf. Dürscheid 1999: 12; Zifonun et al. 1997: 1368). However, there seem to be reasons to assume that there also exists a fundamentally different class of meaningful PO-Ps, one whose independent contribution is due to a reanalysis that has turned formerly lexically selected PO-Ps into surface exponents of a-constructions in the sense of Goldberg (1995). ${ }^{4}$ Such a status of some PO-Ps shows mainly in two ways. The fact that certain PO-Ps occur with several semantically similar heads hints at the presence of a meaningful

\footnotetext{
${ }^{4}$ A referee points to the problems with a Goldberg-style approach discussed in Müller (2006) and Müller and Wechsler (2014), asking whether my proposal could also be accounted for in terms of a lexical approach such as that of Boas (2003; 2011). While I believe Goldberg's a-construction approach can be remedied, such an undertaking is obviously beyond the scope of this paper. As regards an alternative formulation of my approach in terms of a lexical approach, I see no essential problems, insofar as such an approach can be made compatible with the circumstance that also abstract schemas, not just individual cases, may play a role in argument structure generalizations (cf. also Boas 2014 for the need to assume constructions at different levels of generalization). Since the essence of the lexical model is that the valency pattern of an individual verb can function as a model for using another, the question arises whether it can adequately capture novel verb uses resulting from the application of (more) abstract schemas. Goldberg's argument structure constructions, which abstract away from individual verbs, would seem a more adequate tool for this. The way such schemas arise from surface patterns according to the principles of the usage-based model also seems better compatible with Goldberg's approach. Cf. section 3.1 , especially note 26 , for some related discussion.
} 
productive pattern. For instance, the PO-P auf (+ accusative) occurs widely with prospective heads, as in:

(2) a. Er wartet/hofft auf einen Börsensturz.

he waits/hopes on a.ACC stock market crash

'He waits/hopes/is waiting/hoping for a crash of the stock market'

b. Er bereitet sich auf einen Börsensturz vor.

he prepares himself on a.ACC stock market crash before

'He prepares/is preparing for a crash of the stock market.'

c. Wir sind schon sehr gespannt auf eure Zeichnungen.

we are already very excited on your.ACC drawings

'We are already very excited about your drawings.'

d. Denksport macht [einen] neugierig auf mehr. thoughtsports makes one curious on more

'Mental sports make [one] curious about more'

e. Wenn dies eine Aussicht auf Entsatz sein sollte, [...] if this a perspective on relief.ACC be should $[\ldots]$ 'If this was supposed to be a chance for relief, [...]'

Über (+ accusative), on the other hand, often accompanies heads whose complement represents the topic of a mental activity, cf.

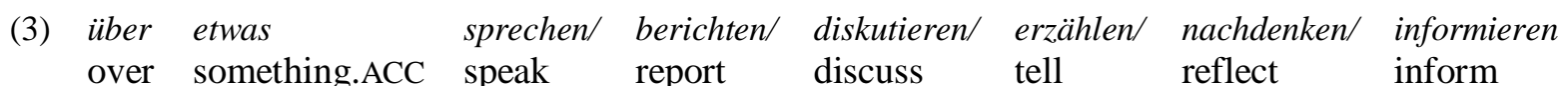

Examples like these can be easily multiplied (cf. e.g. Rostila (2007: 130-131); (2014) for further auf cases) and can be provided for further PO-Ps as well, such as an (+ dative) denoting CAUSE, as in:

(4) a. Er freut sich an den ersten Zeichen des Frühlings. he delights himself at the.DAT first signs of spring 'He delights in the first signs of spring.'

b. Es lag an den Wetterverhältnissen.

it lay at the.DAT weather conditions

'It was due to the weather conditions.'

c. Er starb an Krebs.

he died at cancer.DAT

'He died of cancer.' 
d. Es scheiterte an den ungünstigen Verhältnissen.

it failed at the.DAT unfavourable conditions

'It failed due to the unfavourable conditions.'

e. Er leidet an Herzbeschwerden.

he suffers at heart conditions

'He suffers from a heart condition/has heart troubles.'

A particularly clear example of an a-construction in the guise of a PO-P can be seen in an (+ dative) in cases like

(5) a. Er baute an einem Haus.

he built at a.DAT house

'He was building a house.'

b. Er trank an einem Bier.

he drank at a.DAT beer

'He was drinking a beer.'

c. Er schrieb an einem Buch.

he wrote at a.DAT book

'He was writing a book.'

Each of these verbs normally takes a direct object, i.e. an accusative object, instead of a PO with an, as their complement. However, when combined with a PO with an, the verbs acquire the sense 'ongoing/non-completed activity/process' roughly equal to the contribution of the progressive form in English. By contrast, the corresponding accusative object structures leave it unspecified whether the verb activity or process is in progress, or completed. Since the PO-P an with such an aspectual contribution can be systematically combined with any transitive verb denoting an activity whose stage of completion is recognizable, it is a prime candidate for an a-construction in the form of a PO-P. This aspectual PO-P an has been noted earlier as an example of a PO-P with an independent semantics - i.e. as an exception among the normal, semantically faded PO-Ps, cf. Breindl (1989: 39) - but to my knowledge an a-construction status as the source of the semantic contribution has not been proposed. ${ }^{5}$

One further instance of an a-construction signified by a PO-P, possessive um (+ accusative), will surface in the course of the discussion below; cf. also Rostila (2005: 145; 152; 2006a: 368-370; 2007 : 185-192) for vor (+ dative) denoting CAUSE with predicates like Angst haben (vor X) (lit. 'have fear (before X)'), sich fürchten (vor X) (lit. 'fear oneself (before X)'), nicht schlafen können (vor X) (lit. 'not be able to sleep (before $X)$ '). However, these cases hardly exhaust the potential of finding semantic regularity, i.e. a-constructions, among German PO-Ps. Even a brief look at the list of German PO-structures provided in Duden (1984: 611-614) makes it seem likely that many, if not

\footnotetext{
${ }^{5}$ Cf. also Schøsler (2007: 54) for a similar structure in Danish with the preposition på that would seem to qualify as an aconstruction as well.
} 
most PO-Ps, can be seen as part of some kind of productive pattern built around a common semantic denominator. Many of the patterns extend only to a few cases, however, and what is more, individual PO-Ps often appear as potential members of several different patterns. This suggests family resemblance conditions, and perhaps multiple sources of analogy as well. ${ }^{6}$

I now take a closer look at the question of why the PO-Ps exemplified should be considered independently meaningful and productive. Since in cases like (2)-(5) a certain preposition regularly occurs in conjunction with a certain semantics, while all else in its context varies, it seems natural to interpret the re-occurring semantics, e.g. prospectivity in (2), as the meaning contribution of the preposition. More conclusive evidence for productivity and independent meaningfulness can be seen in cases of coercion, however. Similarly to e.g. the English ditransitive construction (Goldberg 1995: 48), which can impose a CAUSE-RECEIVE semantics on verbs like bake and kick, cf. He baked her a cake/kicked her the ball, some PO-Ps seem to be able to coerce heads into readings that these hardly display themselves. Perhaps the clearest instance of this is prospective auf (+ accusative), cf. (6a-b). It seems to have the potential to impose a prospective semantics on heads: the verb sich freuen 'delight (in something)' usually governing the PO-P über is neutral with respect to whether the cause of joy is situated in the past, present or future; once combined with auf, the verb acquires the sense 'look forward (to something)', and the cause of joy must be interpreted as a future event. Similarly, programmieren 'to program' and trainieren 'to train' are hardly prospective verbs by themselves, but acquire this feature when combined with $a u f,{ }^{7} \mathrm{cf} .(6 \mathrm{c}-\mathrm{d})$ :

(6) a. Ich freue mich über das Ende des Semesters. I delight myself over the.ACC end of term 'I am delighted about/glad of the ending of term.'

b. Ich freue mich auf das Ende des Semesters. I delight myself on the.ACC end of term 'I look forward to the ending of term.'

$\begin{array}{lllllll}\text { c. Das Start-up-Unternehmen } & {[\ldots]} & \text { ist ebenfalls } & \text { auf } & \text { Wachstum } & \text { programmiert. } \\ \text { the start-up firm } & {[\ldots]} & \text { is also } & \text { on } & \text { growth.ACC } & \text { programmed }\end{array}$ 'The start-up firm is also intent on growth.'

d. Resch [...] hatte [...] seine Nerven dar-auf trainiert, [...] Resch [...] had [...] his nerves it-on trained [...] 'Resch had trained his nerves for it'

Cases (6c-d) also illustrate a further property of the auf construction that can only be mentioned in passing here: there seem to exist two variants of the auf construction that are probably diachronically intertwined. While cases like (6b) and (2) illustrate the prospective variant of the construction, cases

\footnotetext{
${ }^{6}$ Cf. Knobloch (2009: 548) for similar conditions among German particle verbs.

${ }^{7}$ In fact, a comprehensive dictionary like Duden Deutsches Universalwörterbuch lists for both programmieren and trainieren prospective, or perhaps rather goal-oriented, uses with auf. I would still maintain that the basic senses of these verbs denote activities without future or goal orientation, and that the dictionary listing of such uses reflect the high frequency with which these verbs are coerced by auf. Cf. below for a similar situation with respect to um.
} 
like those in (6c-d) rather belong to the goal-oriented variant; see Rostila (2014: 104) for further examples. The synchronic and diachronic relationship of these two variants is an obvious object for further study.

Evidence of a slightly different kind for the productivity of the auf pattern is provided by cases where auf occurs in conjunction with nominals, cf.

(7) a. EM-Gastgeber Ukraine: $\begin{aligned} & \text { Favorit aufs Ausscheiden } \\ & \text { EC host }\end{aligned}$ Ukraine: favourite on.ACC dropping out
'E(uropean) $\mathrm{C}$ (hampionships) host Ukraine: favourite for

b. Guttenberg sieht Chance auf Staatshilfe für Arcandor schwinden Guttenberg sees chance on state subventions.ACC for Arcandor disappear 'Guttenberg sees the chances of Arcandor getting state subventions disappear'

c. Auch wenn Minogues Songs hauptsächlich von der Liebe handeln, tragen sie nicht das Versprechen auf romantische Zweisamkeit in sich. the promise on romantic togetherness.ACC in themselves 'Even though Minogue's songs are mostly about love, they do not express the promise of romantic togetherness.'

d. Eine Garantie auf einen solchen [Studien]Platz zu haben, ist enorm wichtig. a guarantee on a.ACC such [study] place to have is enormously important 'It is enormously important to have a guarantee that one can have such a place of study.'

e. das in der US-Verfassung festgeschriebene Recht auf das Tragen von Waffen the in the US constitution stated right on the.ACC carrying of arms 'the right to carry arms enshrined in the US constitution'

Possibly with the exception of Recht, the nominals that seemingly govern auf here are all prospective in their semantics, so one cannot speak of significant coercion effects in such cases. Still, the cases speak for the productivity of a prospective pattern centered on auf. This is because none of the nominals can be argued to govern auf in the normal way. Nominalizations usually inherit the argument marking pattern of the corresponding verb, if the pattern is lexically determined (cf. e.g. Welke 2011: 305); however, verbs like versprechen 'promise', garantieren 'guarantee' and favorisieren 'favour' do not occur with auf, and Chance and Recht are hardly derived from verbs (cf. the dictionary Duden Universalwörterbuch, DUWB). Therefore, data like (7) allow for the interpretation that these nominals are combined with auf because no lexically determined option is available, but the auf pattern is, thanks to its prospective semantics compatible with the nominals.

Further cases of coercion by a productive PO-P can be seen in the unusual verb readings in (8). When combined with the PO-P um (+ accusative) 'about, around', verbs such as schießen 'shoot', schreien 'cry, shout', weinen 'weep', zittern 'tremble', anrufen 'telephone' and fragen 'ask, pose a question, question', along with many others, gain the sense of losing or attempting to acquire or 
maintain something; this sense is hardly associated with the verbs per se, but stems from the productive PO-P um, which I will for want of a better label call the possessive um construction.

(8) a. [...] falls er es doch schaffen sollte,

um sein erbärmliches Leben zu schreien $[\ldots]$
about/around his.ACC pitiful tife to cry
'[...] in case he should manage to cry for his pitiful life $[\ldots]$ '

b. Neuner schießt sich um einen Podestplatz

Neuner shoots herself about/around a.ACC podium appearance

'Neuner shoots herself out of a place on the podium'

c. Er möchte dar-um nicht betteln.

he would like it-about/around not beg

'He would not want to beg for it.'

d. Er zitterte um sein Vermögen. (cf. DUWB, s.v. zittern)

he trembled about/around his.ACC wealth

'He trembled at the thought of losing his wealth.'

e. Die Mutter bangt um ihr Kind. (DUWB, s.v. bangen)

the mother fears about/around her child

'The mother fears for her child.'

f. Er weinte um den Verlust seiner Jugend und [...] he wept about/around the.ACC loss his.GEN youth and [...] 'He wept for the loss of his youth and [...]'

g. Sie betete um seine Heilung. (cf. DUWB, s.v. beten)

she prayed about/around his.ACC recovery

'She prayed for his recovery.'

h. Im vorliegenden Fall war der EuGH in drei Fällen von einem spanischen Gericht um Klärung angerufen worden. about/around clarification telephoned become

'In this case, the European Court of Justice had been called by a Spanish court three times in order to obtain clarification.'

i. jemanden um Rat/Erlaubnis fragen (DUWB, s.v. fragen)

someone about/around advice/permission.ACC ask/question

'to ask somebody for advice/permission'

Further still, cases like (9) demonstrate that also the productive PO-P über mentioned above has an independent semantic contribution to make: when combined with über, verbs like arbeiten 'work' 
and sich beruhigen 'calm down' gain the sense of a mental activity directed at a certain topic not associated with them in their more normal uses:

(9) a. Er arbeitet über Brecht. (Lerot 1982: 273)

er works over Brecht.ACC

'He works/is working on Brecht.'

b. Agnes war es, die sich dar-über nicht beruhigen konnte. ${ }^{8}$

Agnes was it who herself it-over not calm down could

'It was Agnes who could not calm down about it."

Observations like these of course give rise to the question of how to judge whether a head has a certain sense or acquires it by coercion. I have relied on comprehensive dictionaries like the Duden Universalwörterbuch (DUWB) in this respect, deeming verb senses not listed in them as testifying to coercion. However, the case of fragen, cf. (8i), shows that this method is not without its problems. ${ }^{9}$ This verb is indeed listed in the DUWB as also having a sense of attempting to acquire something by posing a question. However, since this sense is only the third one out of a set of four given in the DUWB and involves an additional meaning component ('attempted acquisition') compared to the presumably central sense that is given first, I regard the acquisition component as a contribution of um. In my view, the inclusion of an 'attempted acquisition' sense in the fragen entry reflects the probably high frequency with which fragen is coerced by um; since frequent coercions can presumably result in the establishment of new verb senses (cf. Engelberg 2009: 82; Boas 2011: 1296), dictionaries are not completely in the wrong in listing such verb senses, but anticipate likely developments.

One further indicator of the a-construction status of certain PO-Ps can be seen in the fact that such Ps sometimes occur alone essentially with the same semantics as in cases where a verb or other predicate head accompanies them. Thus in (10a), a common German farewell expression, auf seems to carry the same prospective semantics as in (2). Wiedersehen, 'seeing (one another) again', is presented as a future event with the aid of auf - and perhaps also as a goal of the act of saying farewell, cf. the goal-oriented variety of the construction mentioned above. In (10b), on the other hand, über is used alone to mark its complement as a topic to be broached, i.e. in a way similar to (3) and (9).
(10) a. Auf Wiedersehen!
on seeing-again.ACC
b. Tom Schimmeck über Kreuzzüge gestern und heute
Tom Schimmeck over crusades.ACC yesterday and today
'Tom Schimmeck on crusades past and present'

Independent occurrences like these are presumably only possible under discourse conditions that favour compact expression - conditions like those of greetings (10a) and newspaper headings (10b). ${ }^{10}$ It is conceivable that cases like (10) are elliptical to begin with and then, if they occur frequently, are

\footnotetext{
${ }^{8}$ A German native speaker reviewer finds this example odd. I still choose to use it here, since this is an attested case and might even reflect the creative extension of the über construction to a verb not normally used in it. This might explain the odd flavor.

${ }^{9}$ To define more reliably the central and derived senses of verbs, a polysemy network analysis like that of Fillmore and Atkins (2000), preferably based on a broad body of empirical material, would be needed.

${ }^{10}$ Cf. Östman (2005) and Ruppenhofer and Michaelis (2010) for constructional accounts of the influence of genre.
} 
conventionalized in their shortened form. While this is likely to apply to (10a), (10b) still has a strong elliptical flavor, the verb berichten 'report' being probably the most likely accompaniment of über. Regardless of such differences, such cases support my case for these PO-Ps as manifestations of aconstructions: independent uses like these are to be expected at least under specific conditions if auf and über constitute signs in their own right.

In fact, in some cases productive PO-Ps seem to take on an even greater degree of independence: some of them may be advancing into adjunct use. This is a natural development, ${ }^{11}$ given that gaining the status of an a-construction invests PO-Ps with an independent semantic contribution. Such a contribution is, on the other hand, a requirement for prototypical adjunct heads: they have to be capable of autonomic coding or self-licensing (Oppenrieder 1991: 4-5; cf. Helbig 1973: 155), i.e. prototypical adjuncts are meaningful even in isolation, as e.g. a PP with because of is, in contrast to a complement PP with of also expressing a cause: (I failed) because of you - (He's accused) of it. There seem to be numerous cases where prospective auf displays this kind of behavior, cf. e.g.

(11) a. Das ist auf absehbare Zeit kaum denkbar.

That is on foreseeable time.ACC hardly thinkable

'For the foreseeable future, this is hardly an option.'

b. Aber wird Gemüse und Obst essen auf die Dauer nicht langweilig? but gets vegetables and fruit eating on the.ACC duration not dull 'But doesn't it get dull in the long run to eat [just] vegetables and fruit?'

c. Wohnen auf Zeit

living on time.ACC 'living temporarily/for a time'

Many of such cases have the flavour of conventionalized expressions, e.g. (11a-b) (in fact, I would go as far as deeming the German phrase auf jeden Fall 'in any case' as an instance of prospective auf), but a prospective semantics can nevertheless be discerned in such PPs, while their omissibility and lack of a subcategorization relation to the verb indicates a clear adjunct status. ${ }^{12}$ Thus it seems the independent semantics characteristic of an a-construction has enabled the prospective auf construction to take on the role of an adjunct in certain contexts. Whether such adjunct uses still instantiate the prospective a-construction with auf or some other kind of construction cannot be resolved here; this would require a principled account of the difference between adjuncts and arguments added by a-constructions (but cf. section 4 for some observations on this). ${ }^{13}$

\footnotetext{
${ }^{11}$ Cf. Welke (2009: 540) for complements turning into adjuncts.

${ }^{12}$ In (11c), the auf-PP of course forms an adjunct to a noun, not to a verb.

${ }^{13}$ Kay (2005) is the only such account I am aware of, but does not devote the question its full thrust. In Rostila (2013), I proposed that adjuncts indeed go back to a-constructions, the only difference between adjuncts and arguments added by a-constructions being the way a-constructions fuse with verbs. However, this account still needs further development. Notably, some instances of the goal-oriented variant of auf should be interesting for this, since they seem to straddle the borderline between complements and adjuncts, cf. auf Vorrat essen (lit. 'to eat for stock/reserve'), auf Zeit spielen ('to play for time'), auf $400 €$ jobben ('to work for $400 €$ ').
} 


\subsection{Potential counterarguments}

At least two types of counterarguments to my proposal are conceivable. First, PO-Ps do not systematically display the semantic contributions my proposal ascribes to them. Instead, extensive polysemy and/or homonymy among PO-Ps seems to be the case - cf. e.g. the two productive PO-Ps signified by an (+ dative) discussed in 2.1. Second, all the productive PO-Ps identified by me are less than 100 per cent productive. This might justify calling them patterns of coining in the sense of Kay (2005) rather than constructions. Turning to the problem of polysemy/homonymy first, the inventory of PO-Ps in German certainly contains numerous counterexamples to any of the semantic contributions proposed by me for certain PO-Ps. This can only be illustrated with a few cases here. For example, the instances of the PO-P auf in (12a-c) hardly express prospectivity, and thus seem to form counterexamples to assuming a prospective auf construction:

(12) a. Sie war wütend/stolz auf mich.
she was furious/proud on me
'She was furious with/proud of me.'

b. Er hat dar-auf nicht reagiert.

he has it-on not reacted

'He did not react to it.'

c. Sie hat auf die Frage nicht geantwortet.

she has on the.ACC question not answered

'She did not answer the question.'

d. Diskussion um Gendiagnostik

discussion on/about genetic diagnostics.ACC

'Discussion on/about genetic diagnostics'

e. Die Debatte um den Mindestlohn

the debate about/around the.ACC minimum pay

'The debate on/over minimum pay'

Similar considerations apply to the PO-P um in cases like (12d,e), and the counterexamples could be easily multiplied, for example with topic-presenting verb structures like es geht/handelt sich um X. Such instances of $u m$ are rather associated with a topic to be discussed than with gaining, maintaining or attempting to acquire a possession, cf. possessive um discussed above. Counterexamples of the type illustrated in (12) can be countered by referring to the possibility that the PO-Ps in question are lexically selected by the heads accompanying them, in which case they are virtually without an independent semantics (cf. note 2 for discussion). Alternatively, they might be due to the application of another productive PO-P that has emerged independently of the one whose semantics they seem to call into question. For instance, um might occur systematically enough denoting a topic of discussion to qualify as the exponent of an a-construction in its own right. If no semantic connection to the other um construction can be discerned, such cases have to be regarded as homonymy among a- 
constructions in the form of PO-Ps. The problematic cases to be discussed next, on the other hand, might be due to polysemy among such constructions. ${ }^{14}$

A case in point might be $\ddot{u} b e r$, which in contrast to the $\ddot{u} b e r$ construction proposed above often seems to denote a cause instead of a topic of mental activity:

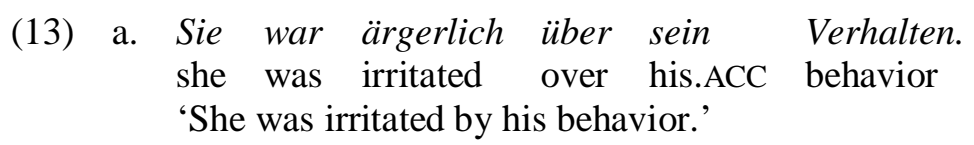

b. Sie haben sich über alles gestritten. they have themselves over all.ACC quarreled 'They quarreled about everything.'

c. 70 Cent müssen Reisende auf vielen Autobahnraststätten für die Toilettenbenutzung zahlen - zu viel, sagen vier von fünf Deutschen laut einer neuen Umfrage. Manch einer wird dar-über zum Wildpinkler [...] becomes it-over to wildpisser 'At many service stations, travellers must pay 70 cent for the use of the toilet - too much, say four out of five Germans. Many choose to urinate outside because of this [...]'

In cases like (13a-b), it can still be argued that the über-PO only denotes a topic of mental activity and hence constitutes an instance of the über construction proposed above. Since states like ärgerlich 'irritated' and activities like sich streiten 'quarrel' presuppose a cause, it is conceivable that they assign a participant role whose essence is $\mathrm{CAUSE}^{15}$. This role fuses with the second argument role of über, and the result is a reading like 'topic causing a negative mental state/activity' for the PO argument.

Cases like (13c) turn out to be more problematic, however. On the one hand, the über-PO would seem to denote a cause here, too - and to constitute an instance of a productive PO. It is hardly subcategorized by werden 'become', yet it does not qualify as an adjunct, either, since über-PPs cannot denote a cause in isolation, cf. *über die Kosten in the sense 'because of the costs' to a typical causal adjunct PP wegen der Kosten 'because of the costs'. Instances of über as in (13c) therefore seem to have the flavor of coercion cases, i.e. cases where an argument structure has been extended to a predicate not normally associated with it. The question is, can they be seen as instances of the proposed über construction denoting mental activity? As I see it, there are two alternatives: either this über construction is at play here, too, and the causal component is a pragmatic inference from the predicate Wildpinkler werden 'become someone who pees in the street'; or (13c) represents the application of a new, slightly modified über construction emerging on the basis of cases like (13a-

\footnotetext{
${ }^{14}$ Both the eventual homonymy and polysemy of a-constructions in the guise of PO-Ps give rise to the question of how the different readings can be activated in the absence of a formal opposition. I think a kind of formal opposition is present despite the appearances, however. It is due to the semantics of the verb or other head embedded in the construction: productive PO-Ps with the same form but different meaning combine with semantically different heads, and only the fusing of the PO-P with a semantically compatible or at least coercible head activates its meaning potential.

${ }^{15}$ Cf. Rostila (2007: 187-192) for a discussion of the plausibility of a role of this type.
} 
b), ${ }^{16}$ a construction more strongly associated with causes than topics of mental activity. ${ }^{17}$ Given the tentative character and narrow empirical basis of these observations, I do not attempt to resolve the matter here; they mainly serve to illustrate the problems of tracking down productive PO-Ps among German PO-Ps. Any serious such attempt probably requires extensive corpus studies, where manual effort cannot be spared because of the semantic issues involved.

As regards the second type of counterargument, productive PO-Ps could be denied construction status on the grounds that their productivity is limited. For instance, despite its seemingly high productivity with prospective heads demonstrated in (2), prospective auf cannot occur with prospective heads like einwilligen ${ }^{18}$ and Plan:

(14) a. Er hat in/*auf die Scheidung eingewilligt. he has in/*on the.ACC divorce agreed 'He agreed to the divorce.'

b. Bush und sein Plan für/*auf den Weltumbau Bush and his plan for/*on the.ACC world reconstruction 'Bush and his plan for world reconstruction'

Possibly with the exception of aspectual an, a similar counterargument can be raised with respect to all the productive PO-Ps proposed by me. Their use cannot be extended to all heads semantically compatible with them. Patterns thus restricted in their occurrence have been called patterns of coining by Kay (2005). In contrast to constructions, which Kay envisages as fully productive within the limits of semantic compatibility, patterns of coining display idiosyncratic restrictions in their applicability: essentially only the cases already established are fully acceptable, cf. e.g. happy as a lark, dry as a bone vs. *young as a chick. To judge from data like (14), productive PO-Ps might seem to constitute a case in point.

It seems to me, however, that the whole division between constructions and patterns of coining is misguided. For one thing, 100 per cent productivity of rule-like phenomena is rare in natural language in the first place (cf. Givón 2002: 121; Stefanowitsch 2007: 167-168), so if this division is maintained, hardly anything can count as a construction. Moreover, data like (14) may not testify to a lack of productivity of prospective auf, but rather to the strength of competing patterns in these particular cases: it is conceivable that ein(willigen $)+i n(+$ acc.) and Plan + für $(+$ acc.) form cases

\footnotetext{
${ }^{16}$ That is, in such cases (especially in (13b)) the PO can be interpreted both as a topic and a cause. This may have provided the link by which mental activity über has developed into causal über.

${ }^{17}$ In fact, the case (9b) also hints at the involvement of such a causal construction: the PP seems not only to denote a topic, but a reason for anxiety as well. This might even be interpreted as an indication that both an über 'mental activity' and über 'activity with a cause' constructions are present - in other words, two sources of analogy are used at the same time.

${ }^{18}$ A referee points out that einwilligen represents an exceptional case in that as shown by Olsen (1997), the preposition in is dependent on the verb particle ein, not on the whole verb einwilligen. If one accepts Olsen's arguments for such an analysis, verbs like einwilligen, einwerfen and einlegen, which all occur with a PO with in, call for a CxG analysis in terms of a construction centered on the particle ein and with a variable slot for a verb (cf. Felfe 2012 for an account of this type for the verb particle an). Such an analysis has no repercussions on the crucial point here: no matter whether the choice of in is due to a particle construction based on ein or to lexical selection by einwilligen, it is apparently capable of pre-empting prospective auf in a context semantically compatible with auf. To accommodate the possibility that einwilligen + in goes back to a particle construction, I use the notation ein(willigen) + in below.
} 
of lexically (or otherwise; cf. note 18) selected PO-Ps entrenched enough to resist conforming to the prospective auf pattern. In other words, in and für pre-empt the use of auf here. Such cases might in fact call it into question whether applicability within semantic compatibility is a sound measure of productivity in the first place: the result might often be more to do with preemption processes than with the productivity of the tested pattern. In any case, there appears to be an independent explanation for the lack of productivity found with productive PO-Ps: competition from other PO-Ps. Against this backdrop, they might even be seen as fully productive, but simply pre-empted by their competitors.

Even without claiming such latent full productivity for this subclass of PO-Ps, there are good grounds for regarding them as constructions - and for not adopting a construction vs. pattern of coining division. As I have discussed in more detail in Rostila (2006b; 2007: 137-144; 2014: 111112), differences in the productivity of schematic constructions could be seen as differences in the degree of grammaticalization that the constructions have attained. Accordingly, the more grammaticalized a construction is, the more open are its slots semantically. Put differently, the less speakers can associate the slots of a construction with particular fillers like happy as a lark, the more grammaticalized it is. ${ }^{19}$ Thus there are just more and less schematic, or grammaticalized, constructions - no patterns of coining besides constructions. Among productive PO-Ps, there is probably a continuum of schematicity, or degree of grammaticalization, from very low to rather high like that displayed by prospective auf. Prospective auf, in turn, displays a low degree of grammaticalization compared to a-constructions belonging to the "core" of grammar, constructions present in most sentences: for instance the German transitive construction signified by the case pair nominative-accusative (cf. Rostila 2007: Ch. 9), and the English transitive and ditransitive constructions, whose high degree of grammaticalization manifests itself in their completely schematic form. ${ }^{20}$

\subsection{On the form and meaning of a-constructions based on PO-Ps}

It is time to take a slightly closer look at what kind of a-constructions PO-Ps constitute. For reasons of space, I will concentrate on the properties of the prospective auf construction, pointing out characteristics representative of the whole class of a-constructions of this type. ${ }^{21}$

Figure 1 below shows the form of the prospective auf construction, an approximation of its meaning, and an example of the way it fuses with an individual verb. I have chosen to present a case where coercion is needed, that of sich auf etwas freuen (cf. 6b). To start with the easiest part, the form

\footnotetext{
${ }^{19}$ The principles of the usage-based model (cf. e.g. Bybee 2006) can account for how the slots become more open: the more fillers have appeared in a particular slot, the less clear idea speakers have of "correct" fillers, and the more tolerant they presumably grow of potential new fillers.

${ }^{20}$ A referee expresses doubts as to the semantic purport of the nominative-accusative (i.e. transitive) construction in German, and hence questions my classifying it as an a-construction. See Rostila (2007: Part III) for arguments for the independent meaningfulness of the nominative-accusative pattern in German. These arguments presuppose the notion of logico-pragmatic roles (called perspectival roles in Rostila 2007) worked out in Welke (2002), as well as Welke's (e.g. 1994; 2002) truly prototypical approach to semantic roles. On a view based on these notions, nominative-accusative can be argued to express PROTO-AGENT/1 - PROTO-PATIENT/2, where 1 and 2 roughly correspond to TOPIC and FOCUS. It is important to note that unlike Müller and Wechsler (2014: 21), and in keeping with a significo-semantic approach to meaning (Welke 1994; 2002; Rostila 2007: 49-51), I do not require a truth conditional semantic contribution of the German nominative-accusative construction in order for it to be meaningful.

${ }^{21}$ I will also restrict myself to PO structures in sentences with two arguments; possible a-constructions based on PO-Ps in structures where the predicate verb is accompanied by three or more arguments, cf. e.g. Sie (1) hat ihn (2) in das Geheimnis (3) eingeweiht ('She let him in on the secret'), are outside the scope of this paper.
} 
of the construction: the sole phonetic exponent of the construction is the PO-P auf along with the accusative case that together mark the construction's second argument; since the choice of a certain PO-P always determines the choice of case, the PO-P and the case are in effect to be seen as one sign in all PO-P structures. Although the subject, or first argument of the construction, always carries the nominative case, this case rather belongs to the form of the nominative: $1^{\text {st }}$ argument construction (cf. Rostila 2007: 341), ${ }^{22}$ the rough German equivalent of a subject-predicate construction, since virtually all subjects carry the nominative in German. ${ }^{23}$ The same goes for all a-constructions of this class.

Form:

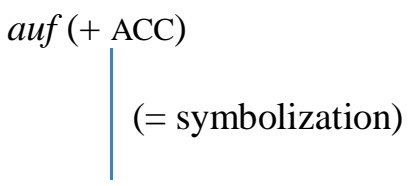

Meaning: $\quad$ FUTURE-ORIENTED ENTITY/1

FUTURE EVENT/2

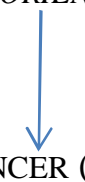

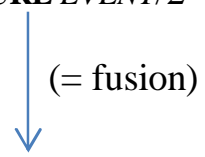

sich freuen: EXPERIENCER (incl. ORIENTED ENTITY) OF JOY

STIMULUS OF JOY (incl. EVENT)

Figure 1: $\quad$ Fusion of prospective auf construction with sich freuen

As regards the argument structure of the construction, PO-P constructions of this type first of all have two arguments. The numbers 1 and 2 refer to perspectival roles roughly equivalent to the syntactic functions subject and object; as argued in Rostila (2007: Ch. 2), such roles, adopted from Welke (1988; 2002), have certain advantages over both the notion of profiling employed in Goldberg (1995) and the traditional notion of syntactic functions (cf. 3.2 below for some detail). The roles of first and second argument are associated with argument roles, whose content may form the most controversial part of the construction. I have arrived at approximations of the semantics of the two arguments by comparing instances of the construction like those in (2), trying to extract the common semantic denominators of the arguments. In addition, I have considered cases like Er wartet auf den Stein 'He waits/is waiting for the stone', where the contents of the second argument become maximally transparent due to minimal overlap with the inherent meaning of the NP embedded in the second argument position (an NP like der Stein/the stone cannot inherently denote an event). Such

\footnotetext{
${ }^{22}$ In Rostila (2007), I assume the following a-constructions based on the case pair nominative-accusative or nominative alone: nom-acc: AGENT/1-PATIENT/2, nom: AGENT/1, nom-acc: 1-2, nom: 1. In the latter two cases, the constructions only express perspectival roles (cf. note 20) and serve as a way to capture structural cases.

${ }^{23}$ A referee points out that there are German sentences without subjects such as 1) Ihn dürstet nach Erfolg ('He craves for success'; lit. 'him hungers after success'), 2) Ihm graut vor der Prüfung ('The exam terrifies him'; lit. 'him terrifies before the exam') and 3) dass noch gearbeitet wurde ('that it was still worked'; lit. 'that still worked was'). Such cases give rise to the question of what contributes the contents of the nom: 1 construction here. Even though there are variants of 1) and 2) with a nominative subject (Ihn dürstet es nach Erfolg and Mir graut es vor der Prüfung respectively), the question is relevant. Within the system proposed in Rostila (2007), a-constructions serve as a means of linking for verbs whose linking pattern is to a large degree regular. Such verbs fuse with a-constructions solely on the basis of their semantics without recourse to any kind of lexically specified, idiosyncratic information regarding linking. However, the system also allows for more peripheral linking patterns specified for individual lexical items. Non-productive, i.e. ordinary, PO-Ps go back to such patterns, the verbs in 1) and 2) likewise. Such patterns, which may have accusative and dative subjects (cf. Rostila 2007: 59-61 for discussion) express the same kinds of contents as a-constructions (cf. Rostila 2007: 300-301; 309). For German dependent clauses like 3), where the expletive subject es cannot accompany the passive, a separate construction with information structural content needs to be introduced. The observations on the information structural contribution of $e s$ in Rostila (2007: 342-348) might serve as a basis for it, but the details cannot be worked out here.
} 
methods are of course lax and rely all too much on intuition, but have to do in the absence of more objective ones. As regards the name labels of the arguments, it should be borne in mind that aconstructions based on PO-Ps represent generalizations on a rather low level; one should not therefore expect of them familiar semantic roles like AGENT, PATIENT, RECIPIENT, which only emerge from higher-level generalizations producing more grammaticalized a-constructions like the German transitive construction.

Moving on to the fusion of the construction with the verb sich freuen, it is first of all notable that the participant roles of the verb are not lexically associated with perspectival roles. This reflects the attempt undertaken in Rostila (2007) to posit only idiosyncratic linking information as part of lexical entries. As regards the compatibility of argument and participant roles, I have indicated in boldface the semantic components that the construction imposes on the verb participants. Italics, on the other hand, indicates overlapping semantic components. Apart from the component FUTURE, the fusion illustrated here is a straightforward case of the verb's forming a subtype of the event expressed by the construction (cf. Goldberg 1995: 65), i.e. the participant roles are specific instances of the more general argument roles (provided that one accepts my assumption that EXPERIENCERS are ORIENTED ENTITIES, and all STIMULI amount to EVENTS). ${ }^{24}$ The assumption that an a-construction can - within certain limits - impose its semantics on a particular verb is based on a concept of coercion like that proposed by Michaelis (2004). Michaelis's notion that grammatical constructions can override lexical constructions semantically ties in well with my assumption that a-constructions are products of grammaticalization, i.e. grammatical items forming closed classes.

Notably, the representation contains no indication of the required semantic relation between verb and construction that figures fairly prominently in Goldberg's (1995) approach. This is because I consider it in two respects premature to define such relations. First, it is doubtful whether the acceptable semantic relations between a-constructions and verbs embedded in them are conventionalized to a degree that justifies representing the relation as part of a construction; it should be borne in mind that constructions are meant to capture conventionalized linguistic knowledge. In Rostila (2007: 179-180), I view such relations as "usage preferences" (Stefanowitsch 2008: 247), which nevertheless have a potential for conventionalization, and base the fusion of verbs and constructions solely on the presence of semantic overlap between participant and argument roles. Second, any proposal regarding such conventionalized relations between a-constructions based on PO-Ps and verbs embedded in them would require an extensive corpus study that was not possible within the format of Rostila (2007).

To further motivate constructions of the type described in Figure 1, I will close by showing that also the analysis of the complements of verbs of motion and position, cf. (15), requires a-constructions closely resembling productive PO-Ps.

$\begin{array}{rlll}\text { (15) a. Peter geht in den } & \text { Korridor. } \\ \text { Peter goes into the. ACC corridor }\end{array}$

\footnotetext{
${ }^{24}$ A referee points out that not only events but also states can occur as the second argument of the auf construction, cf. e.g. Er freut sich auf das Tot-Sein 'He looks forward to being dead'. This is no problem for my proposal, since the argument roles of the construction are prototypical in nature, and the categorization of a state as an event is a plausible case of coercion.
} 
'Peter goes into the corridor.'

b. Der Wagen liegt im
the car lies in the. ACC
'The car lies in the ditch.'

PP complements with local Ps like those in (15) should be described as a-constructions within a Goldberg-style $\mathrm{CxG}$ approach, since they can be productively combined with whole classes of verbs, i.e. positional and movement verbs. Abstracting away from differences between German and English, and using square brackets to indicate schematic parts, such constructions can be described in the following way:

(16) a. $\left[1^{\text {st }}\right.$ argument/THEME $]$ [Verb of movement $]$ [directional expression $\left.=2^{\text {nd }} \operatorname{argument} / \mathrm{GOAL}\right]$

b. [1 $1^{\text {st }}$ argument/THEME] [Verb of position] [locative expression $=2^{\text {nd }}$ argument/LOCATION $]$

Such constructions are more schematic in their form than a-constructions describing productive POPs: there is a variable slot for locative and directional expressions here that not only accommodates prepositional phrases, but even adverbs like dorthin 'there (directional)' or dort 'there'. By contrast, constructions describing productive PO-Ps specify a certain preposition, e.g. auf. Otherwise, the only difference to productive PO-P constructions is a semantic one: constructions like (16) denote more concrete semantic roles than those underlying productive PO-Ps (cf. figure 1 above). This reflects their degree of grammaticalization, which is lower than that of productive PO-Ps. The constructions in (16) will be of relevance for the discussion in section 4.

\section{How do productive PO-Ps emerge?}

The discussion so far has shown that there are good grounds for regarding productive PO-Ps as a-constructions. My aim here is to outline and to some degree refine the scenario proposed in Rostila $(2005 ; 2007 ; 2014)$ for how productive PO-Ps emerge diachronically. Given that productive PO-Ps represent a-constructions, this scenario might be informative with respect to how a-constructions in general come into being diachronically. This in turn is a crucial question, since work within $\mathrm{CxG}$ has hitherto largely neglected the diachronic dimension of a-constructions, concentrating on their development in child language instead (cf. Tomasello 2003; Goldberg 2006), ${ }^{25}$ and there is considerable controversy as to whether the diachronic emergence of a-constructions can be considered a case of grammaticalization, as the later discussion of Schøsler (2007) and Noël (2007a,b) will show. The scenario presented here is highly hypothetical in that it is largely not based on diachronic data, but relies on parallels to known cases of grammaticalization and insights into generalization in child language for corroboration. Its main raison d'être is to provide points of departure for future diachronic corpus studies of the development of productive PO-Ps in German that could put it on a more empirical footing.

\footnotetext{
${ }^{25}$ See Rostila (2007: 194-197) for discussion; cf. also Fried (2009).
} 


\subsection{Parallels to known cases of grammaticalization}

I assume that productive PO-Ps emerge as generalizations across several cases where semantically similar predicate heads lexically select the same PO-P. For instance, prospective auf may have developed as a generalization across several semantically similar PO structures like (2) above. The usage-based model (e.g. Langacker 1987; Croft and Cruse 2004; Bybee 2006; Rostila 2006b) suggests that under such circumstances, language users form generalizations regarding both the form and the meaning of parallel cases. Concrete commonalities, e.g. auf, are stored as such, while schematic parts, or slots, are substituted for material whose form varies. Semantic commonalities of the parallel cases are stored as the meaning of the emerging (partially) schematic construction, and as semantic conditions on slot fillers. According to the usage-based model, the emergence of such generalizations requires type variation, i.e. the existence of several parallel cases. This view may require some refinement, though. It is at least tempting to hypothesize that e.g. possessive um might have developed essentially on the model of German bitten 'ask (in order to gain/possess)' alone, a presumably highly frequent verb $+u m$ combination whose meaning coincides with the core semantics of the construction. A similar argument could be made with respect to prospective auf, for which warten 'wait' might have formed the prototype. The central role that individual high-frequency cases seem to play in the development of a-constructions in child language (see 3.3 below for discussion) suggests that this is a possibility that should be looked into in diachronic corpus studies of the emergence of productive PO-Ps. This is all the more so because Boas $(2003 ; 2011)$ has proposed an appealing approach relying on individual cases, or "mini-constructions", as a source of analogy instead of broad generalizations like Goldberg-style a-constructions.

Choosing between the two approaches is, however, not necessary here, since the parallels I see between the emergence of productive PO-Ps and certain processes of grammaticalization stand regardless of whether the reanalysis I am about to argue for requires type variation to come about, and whether it produces a broader or a narrower generalization. ${ }^{26}$ Instead, it is crucial for these parallels, and for the generalizability of the grammaticalization of PO-Ps to a-constructions in general, that the diachronic starting point of the development consists in traditional PO structures, where the $P$ is lexically selected by a certain head. This is because such structures, due to their head-specific argument marking, closely resemble verb islands (or more generally, item-based constructions; Tomasello 2003: 139), which in turn form the basis of the emergence of a-constructions in child language.

Evidence for lexically selected POs being the diachronic source can be seen in the fact that synchronically most POs seem to belong to this type, with only a few cases having advanced to a truly productive status. More concrete evidence with respect to prospective auf is provided by Hundt

\footnotetext{
${ }^{26}$ In fact, it does not seem clear there is a need to choose between the options in the first place. If abstract schemas indeed play a crucial role in generalizations regarding argument structure along with highly frequent individual cases in both ontogeny and phylogeny, as experimental work by Goldberg (2006), the historical study of a-constructions by Israel (1996), and also Bybee's (2003) account of the grammaticalization of can in English suggest, both options seem to be needed (cf. also Boas 2014). Which of the two dominates in a particular case might depend on whether there is a lot of type variation or a few high-frequency cases present in a pattern at a certain moment. Even in the case that a single verb along with its argument marking pattern functions as a model, I would still see an a-construction at work, however. From my point of view, a-constructions are nothing but knowledge of what kinds of generalizations can be made. Even a generalization on the basis of a single verb produces such knowledge, but in such cases, the generalization remains nearly indistinguishable from the individual verb in its argument marking pattern; in other words, the slots of the emerging construction remain relatively closed (cf. note 19). The more individual cases participate in the generalization, the more abstract it is, and the more clearly there is an a-construction in addition to individual cases.
} 
(2001), whose historical account shows how warten 'wait', synchronically probably the most central verb occurring with prospective $a u f$, first selected virtually freely among directional prepositions, until finally the choice was narrowed down to auf. Rostila (2005: 146-149) provides a more detailed discussion of the process; at its core seems to have been a development where the preposition that was most often semantically compatible with the verb, auf, was finally stored as part of the verb entry. I assume similar processes have created the bulk of present-day PO structures in German, which, unlike prospective auf, aspectual an, and a few other cases like those of über and um discussed in section 2, essentially remain lexically selected. Contrary to the views of Hundt (2001) and Kolehmainen (2010: 36), and in agreement with Brinton and Traugott (2005: 123), ${ }^{27}$ I deem such a development stage a manifestation of lexicalization, not yet grammaticalization: so far, only a complex lexical entry consisting of a predicate head and the preposition governed by it has been created. Only after the formerly lexically selected PO-P has been reanalyzed as a partially schematic construction, i.e. as an a-construction, can one speak of grammaticalization. This step manifests itself as the possibility of productive use; how this step probably takes place will be discussed next.

There are several known cases of grammaticalization that display striking similarities to what seems to happen to PO-Ps when they become productive. I will discuss two of them here and compare them to the case of prospective auf becoming productive. The cases in point are the textbook example of grammaticalization, ne ... pas in French, and the development of words meaning 'hand' into affixes of manner in some native American languages discussed by Mithun (2002). ${ }^{28}$ In each of these cases, an element X (auf/pas/word meaning 'hand') is first stored as part of several semantically similar constructions, loses its lexical meaning while "jailed" like this, and is eventually reanalyzed as a carrier of a more abstract meaning that derives from its "jailers". In the following, I will present the three cases in parallel, as they go through these three stages. The focus will necessarily be on the similarities of the cases; for more historical detail, see Detges and Waltereit (2002), Price (1997) and Rostila (2006b) for ne ... pas, Mithun (2002) for the affixes of manner.

Stage 1: $\mathrm{X}$ is frequently used with a certain (lexical or more complex) construction $\mathrm{Y}$. X still has a full lexical meaning and constitutes a construction in its own right

- The word pas 'step' is frequently used with the simple negation $n e(=\mathrm{Y})$ and a verb of motion embedded in this negation construction in order to give rise to the pragmatic inference 'emphatic negation' (cf. Detges and Waltereit 2002).

- A noun with the meaning 'hand' is frequently combined with certain verbs to narrow down their meaning (cf. Mithun 2002).

- A directional lexical preposition like auf is frequently combined with certain verbs, e.g. warten and zielen (present-day meanings: 'wait', 'aim'), since its meaning was the most compatible with the verb's typical directional arguments. ${ }^{29}$

Stage 2: High token frequency of $\mathrm{X}+\mathrm{Y}$ entrenches $\mathrm{X}+\mathrm{Y}$ as a unit/construction; the lexical meaning of $X$ starts to fade, since $X$ is now part of a larger construction that can be processed as a whole (cf. Rostila 2006b for discussion). Possible former pragmatic inferences are stored as part of the meaning of $\mathrm{X}+\mathrm{Y}$.

\footnotetext{
${ }^{27}$ Cf. also Lehmann (2002: 12), who only sees the discontinuity of verb + preposition combinations as an obstacle to classification as cases of lexicalization.

${ }^{28}$ For further similar cases, cf. Rostila (2006b; 2014: 107).

${ }^{29}$ Cf. Rostila (2014: 107) for more detail.
} 
- The meaning 'emphatic negation' is conventionalized for ne ... pas; the loss of the lexical meaning of pas shows in the gradual spread of ne ... pas to verbs other than those of motion.

- The combinations verb + noun 'hand' are lexicalized; the meaning 'hand' fades, since the combinations are now "learned and accessed by speakers as units" (Mithun 2002: 248).

- Due to the high frequency of co-occurrence, a preposition like auf is stored with verbs whose complement it often used to head; discontinuous lexical entries of the type verb + preposition, i.e. lexically selected PO-Ps emerge. Storage as part of a larger construction starts to fade the original lexical meaning of the preposition. In addition, pragmatic inferences may be stored as part of the meaning of the arising complex verb entries, cf. Rostila (2005: 145-148; 2014: 108) for discussion.

Stage 3: $\mathrm{X}$ is reanalyzed as a carrier of a meaning that can be assigned to it on the basis of the overall meaning of X + Y (cf. the process called "blame assignment" by Tomasello 2003: 297). ${ }^{30}$ The reanalysis may require the existence of several parallel cases $X+Y 1, X+Y 2, \ldots$. The new meaning of $\mathrm{X}$ is in this case a generalization over the meanings that speakers assign to $\mathrm{X}$ in the parallel cases. Compared to the original lexical meaning, the new meaning of $\mathrm{X}$ is more abstract. In other words, $\mathrm{X}$ has grammaticalized due to storage as part of a larger construction and a reanalysis as a sign/construction. X's reinstatement as a construction in its own right shows in its independent use.

- After ne ... pas has been degraded to a standard negation due to inflationary use (cf. Detges and Waltereit 2002: 184), speakers start to use pas alone as a negation, i.e. the colloquial negation pas arises. In other words, pas has been broken out of the larger construction ne ... pas and reanalyzed as carrying the meaning of this construction. It now constitutes a partially schematic construction in itself, one essentially restricted to colloquial language.

- Speakers reanalyze the element formerly meaning 'hand' as an affix with a meaning ('manner') that they have assigned to it on the basis of several cases where this element has been lexicalized with a verb. New verbs can now be derived with the aid of the affix (cf. Mithun 2002: 248).

- Speakers reanalyze a PO-P like auf as carrying a meaning that they can assign to it on the basis of several semantically similar verb + PO-P combinations. An a-construction, whose sole concrete part is the preposition in question, arises. This construction can now be productively applied to verbs that did not combine with the preposition earlier.

In each of these cases, the result is a partially schematic construction whose sole concrete surface exponent is X. If the cases of pas and the affixes of manner (along with further similar cases; cf. Rostila 2006b; 2007: 138-144; 2014: 106-112) can count as grammaticalization, I see no reason why that of PO-Ps should not, too; see 3.2 below for further discussion. ${ }^{31}$

\footnotetext{
${ }^{30}$ Cf. also Croft's (2000: 126-127) hypoanalysis.

${ }^{31}$ It may seem like I have confused grammaticalization with exaptation (e.g. Lass 1997: 316) or regrammaticalization (e.g. Askedal 2006) by stressing that the grammaticalizing item lacks an independent meaning before its actual grammaticalization. However, if this argument were valid, the case of pas, a textbook example of grammaticalization, would constitute a case of exaptation as well. My claim is that most, if not all, processes of grammaticalization involve stage 2, where the grammaticalizing item loses its independent meaning. The verdict can only read 'exaptation' if the fact that they have carried independent meanings before this stage is ignored. A further point worth noticing is that from a
} 
The question now arises, however, to what extent the parallels between the cases are real. As regards pas and the affixes of manner, I have above merely given constructional interpretations of accounts by others that rely on historical data. As regards PO-Ps, it is at least a historical fact that their choice was fixed with certain verbs, and present-day coercion cases show that some of them later did become productive, i.e. were reanalyzed as partially schematic constructions. Whether the high frequency of verb + preposition co-occurrence (Stage 1) and the existence of several combinations of certain PO-Ps with semantically similar verbs as a prelude to the productivity of such PO-Ps is a historical fact is something that remains to be established on the basis of historical corpora. In addition to these questions, some further points of departure for future historical corpus investigations into the rise of productive PO-Ps can be defined. I will return to these after discussing the approaches of Schøsler (2007) and Noël (2007a,b) to a-constructions and grammaticalization. As a preliminary, it must be stated that these accounts do not necessarily represent the most recent thinking of these scholars regarding the issue of a-constructions and grammaticalization. Nevertheless, they are useful in that they can be used to clarify my claims regarding the issue.

\subsection{A-constructions and grammaticalization: a controversial issue}

Schøsler (2007) regards processes where verb valency patterns acquire a specific content and as a consequence specialize to accompany certain verbs as cases of grammaticalization. Of specific interest here is the case of the valency pattern subject - indirect object $(S-I O)$ in French, since this case is studied diachronically. To put it briefly, this pattern seems to have been without content earlier, but has specialized to express something like STIM(ULUS) - EXP(ERIENCER), and therefore now combines with a narrower class of verbs than earlier. What is crucial here is that Schøsler (2007) considers a semanticization of a verb valency pattern to be a case of grammaticalization. This is also at the core of my proposal: lexically selected PO-Ps are valency patterns without independent meaning (cf. below for discussion) that in some cases are reanalyzed as meaningful, and this process, provided that it proceeds as outlined in the previous section, is a case of grammaticalization. However, for reasons not quite clear to me, Schøsler (2007: 60) is not willing to consider semanticisized valency patterns as a-constructions; from my point of view, they clearly fall into this class, since they combine a pattern of syntactic form with content characteristic of a-constructions: syntactic functions paired with semantic roles. ${ }^{32}$ In contrast to my approach, Schøsler (2007) offers no hypothesis for how the semanticization of the $\mathrm{S}-\mathrm{IO}$ pattern took place, but she also sees the meaning of verbs as the source of the meaning (Schøsler 2007: 61) - cf. stage 3 in the grammaticalization scenario of 3.1 .

An essential contrast between my approach and that of Schøsler (2007) is to be seen in the fact that the semanticization of a pattern like S - IO is from my point of view rather a case of degrammaticalization. This is because the meaning of this pattern seems to have been more general before it specialized to express STIM - EXP. I therefore deem the origins of the pattern roughly on a par with a-constructions like the English transitive and ditransitive constructions, or the German nominative-accusative construction (Rostila 2007) with respect to the degree of grammaticalization - i.e. the pattern was already an a-construction grammaticalized to a very high degree before it

$\mathrm{CxG}$ point of view, it makes only limited sense to speak of a grammaticalizing lexical item (like pas). Such an item ceases to be an independent sign at stage 2; from then on, the process of grammaticalization pertains to a complex construction.

32 Syntactic functions display at least information structural content, provided that they are conceived of as perspectival/logico-pragmatic roles in the sense of Welke (2002); see the discussion of Noël (2007a,b) below for some detail. 
specialized. By contrast, the point of departure with PO-Ps is an idiosyncratic, lexically determined valency pattern that is without semantic content due to lack of commutation, ${ }^{33}$ and the result of the process of grammaticalization is a productive pattern with still a much more specific meaning than that of highly grammaticalized a-constructions like the English transitive and ditransitive constructions. From my point of view, therefore, Schøsler (2007) seems to have discussed a special case in the development paths valency patterns may take: a highly schematic a-construction becoming more specific in its meaning. My claim is that the more common way is from verb-specific patterns to a-constructions - the way PO-Ps seem to take. ${ }^{34}$ Grounds for this are to be seen in the fact that this is the way a-constructions emerge in child language; see 3.3 below for discussion.

Noël (2007a,b) raises objections against Schøsler's (2007) proposal of considering the semanticization of valency patterns as a case of grammaticalization - and against considering aconstructions in general as products of grammaticalization. It appears, however, that his three main objections can be refuted. This strengthens the case for regarding the development of productive POPs, and that of a-constructions in general, as a grammaticalization process.

First, Noël (2007a; cf. 2007b: 193-194) points out that a gain in semantic content is not compatible with the main tenets of grammaticalization theory, which rather associate a loss of meaning with grammaticalization processes. Admittedly, this counterargument applies to the case of the pattern S - IO specializing semantically, but as just discussed, this is arguably a case of degrammaticalization, and a gain in meaning is therefore to be expected. The emergence of productive PO-Ps, which I assume to be representative of the diachronic emergence of a-constructions in general, is a different process, one in which the means that used to express the participant role(s) of a verb come to express more general meanings, i.e. generalizations over sets of participant roles. Such a direction of semantic development is of course in keeping with the tenets of grammaticalization theory. What is more, if the process leading to the emergence of productive POPs is considered in its entirety, i.e. from stage 1 to 3 , it is even more clearly a case of semantic loss: the point of departure is a local lexical preposition, ${ }^{35}$ as the grammaticalization scenario of 3.1 shows.

However, there seems to be a contradiction in my claims regarding the meaningfulness of lexically determined PO-Ps that has to be clarified. Above, I stated that lexically determined valency patterns like PO-Ps at stage 2 of my scenario are devoid of meaning; here I just said they express participant roles. Illogical as it may seem, both of these claims are valid. I must refer to Rostila (2007: 119-129) for a fuller discussion; here I can just give the gist of it. ${ }^{36}$ As long as PO-Ps like auf are lexically determined markers of certain heads, they do symbolize the participant roles of certain

\footnotetext{
${ }^{33}$ That is, since the pattern cannot be substituted for another, it cannot constitute a sign at this stage.

${ }^{34}$ In fact, it is possible that even the S - IO pattern studied by Schøsler (2007) gained its a-construction status in much the same way as productive PO-Ps: the pattern may have been entrenched with certain verbs displaying STIM-EXP semantics and then reanalyzed as an a-construction; in other words, S - IO would have been the X of my grammaticalization scenario presented in 3.1. Noël (2007b: 193) makes a similar proposal, ascribing the STIM-EXP semantics to an individual verb frequently occurring in the S - IO pattern. Even if S - IO semanticized along these lines, I would still label the development degrammaticalization: it is crucial that the point of departure, the original $\mathrm{S}-\mathrm{IO}$ construction, was more grammaticalized than the outcome.

${ }^{35}$ To be exact, the point of start is the insertion of a local lexical preposition into an a-construction like those presented in (16); cf. section 4 for some discussion. Both constructions involved at this stage - the lexical construction consisting in a particular local preposition and the a-construction in which it is embedded - are more concrete in their meaning than the outcome of the process, a productive PO-P, so the whole of the development accords with the tenets of grammaticalization theory.

${ }^{36}$ Notably, the approach based on secondary and primary signs developed in Rostila (2007) can also be applied to the account in Nunberg et al. (1994) of the meaningfulness of parts of idioms.
} 
heads, but this meaning potential is restricted to the context of these heads - it is not valid across the board, i.e. in the whole of the German language, unlike the meaning of, say, words like Baum 'tree'. At this stage, PO-Ps count as signs within other signs, the other sign in this case being the discontinuous lexical unit consisting of a verb and a PO-P. In Rostila (2007: 128), I call such signs secondary signs, in contrast to primary signs like Baum whose meaning is valid in the whole of a particular language. A secondary sign is only assigned a meaning when language users analyze the sign that contains them into their component parts; however, they can also choose to employ them as unanalyzed wholes, and in such cases, component parts remain without meaning assignment. This is how lexically determined PO-Ps can be regarded as being both meaningful and devoid of meaning at the same time. ${ }^{37}$

Noël's (2007a; cf. 2007b: 186; 198, n. 15) second counterargument reads that existing diagnostics of grammaticalization like decategorization and reduction only apply to processes involving concrete elements like pas. Completely schematic constructions like Schøsler's valency pattern S - IO would be outside of their scope. Now, if the above arguments for deeming the specialization of this pattern a case of degrammaticalization hold, these criteria in fact should not apply to it.$^{38}$ Nevertheless, they are at least in principle applicable to completely schematic constructions: their next stage of decategorization and reduction is complete disappearance. The criteria are also applicable to the process of lexically determined PO-Ps becoming productive: a lexical item like auf loses its status as a local lexical preposition and becomes the surface manifestation of an a-construction with a more abstract meaning. Presumably in the further course of grammaticalization, auf may also be phonetically reduced; highly grammaticalized a-constructions like the English transitive and ditransitive constructions show that a-constructions can even shed all of their phonetic substance. Such constructions in turn represent the highest grade of grammaticalization among a-constructions. The criteria of decategorialization and reduction apply to such truly fully schematic a-constructions insofar as they have been reduced from a-constructions symbolized by morphological cases (cf. the German transitive construction symbolized by the case pair nom-acc; Rostila 2007: 266) and can be further reduced to zero, which in this case means the demise of the construction.

Noël's third argument against considering the semanticization of the S - IO pattern a case of grammaticalization is to do with the semantics of a-constructions in general, and hence potentially discredits the idea of deeming a-constructions as products of grammaticalization regardless of the way they have arisen. He points out that the meanings expressed by a-constructions - e.g. roles like STIM and EXP - are propositional, not interpersonal, in contrast to prototypical grammatical meanings (2007a: 74-75). This view ignores an important meaning contribution of a-constructions. Aconstructions do not just signify semantic roles, but also the syntactic functions that the construction associates with its arguments (cf. Rostila 2007: 61-65). These functions can in turn be interpreted as meaning categories. In Goldberg (1995: 26; 49), they amount to profiling differences; in Rostila (2007), I prefer to call them perspectival roles, because this notion, adopted from Welke (logicopragmatic roles; e.g. 1988; 2002), connects more explicitly to information structural categories like

\footnotetext{
${ }^{37}$ The same idea can be applied to the case of pas as well. At stage 2, this element can only be assigned the meaning 'emphasis of negation' within ne ... pas (elsewhere pas means 'step'); at stage 3, pas becomes a primary sign, or an independent construction, symbolizing NEGATION in the register of colloquial French.

${ }^{38}$ Strictly speaking, this pattern is not even an example of a completely schematic construction: it displays a concrete element, the preposition à used to mark the indirect object.
} 
TOPIC and FOCUS. ${ }^{39}$ Simplifying somewhat, part of the meaning contribution of a-constructions are categories like TOPIC and FOCUS, and such categories are clearly interpersonal, hence grammatical also by Noël's (2007a) standards. ${ }^{40}$

To sum up, at least Noël (2007a,b) fails to give compelling arguments against a-constructions as products of grammaticalization. Admittedly, to grant them this status, it seems justified to require that semantic generalization, or bleaching, is involved in their development, as Noël $(2007 a, b)$ does. For those a-constructions that emerge as generalizations over classes of individual verbs, this is a matter of course, however. Next, I will briefly turn to the question of why this should be the normal way aconstructions emerge on the diachronic axis.

\subsection{Parallels between the emergence of a-constructions in child language and their diachronic emergence}

Studies of child language (cf. Tomasello 2003; Goldberg 2006) suggest that a-constructions emerge as generalizations over groups of verb islands. In such groups, the verbs display semantic similarities and the same argument marking pattern; initially, the child does not recognize these parallels, however, hence the term 'island'. The process of generalization seems to be catalyzed by input where a single verb island dominates at first, followed by a more balanced distribution of cases (cf. Goldberg 2006: 79; 89-90; Goldberg et al. 2007). In other words, a mixture of high token frequency of individual cases and some type variation seems to be required. ${ }^{41}$ Individual highfrequency cases that are presumably stored as such appear to provide a concrete point of reference for the learning process (cf. Goldberg et al. 2007; Avrahami et al. 1997); generalizations seem to emerge in an interplay of such concrete points of comparison, the presence of further similar cases and, later on, abstract schemas derived from the concrete cases (cf. Goldberg 2006: 79). Now, assuming that this picture of the emergence of a-constructions in child language is somewhere near correct, it seems useful to consider whether it might also capture the essence of their diachronic emergence. $^{42}$

Arguments for considering the ontogeny of a-constructions informative of their phylogeny can be based on the diachronic study by Israel (1996) of the English way construction (e.g. The wounded soldiers limped their way across the field) and on facts known about German PO structures. Turning to the way construction first, Israel's study suggests that the diachronic emergence of this construction was driven by analogical extensions from individual cases and abstract schemas formed on the basis of clusters of verbs occurring in the construction. The similarities to the findings of Goldberg (2006) regarding the role of high-frequency individual cases and abstract schemas in child-language generalizations are obvious. Thus parallels between the ontogeny and phylogeny of a-constructions seem to be worth taking seriously.

\footnotetext{
${ }^{39}$ A referee expresses doubts about a connection between syntactic functions and information structural status. Indeed, such a connection can only be worked out within Welke's (e.g. 2002) two-level theory of perspective, which can accommodate changes in information structure enabled by the relatively free constituent order of languages like German. ${ }^{40}$ Noël (2007b: 195) seems to revise his position regarding the status of semantic roles and is now willing to accept them as grammatical meanings. As shown, even without this concession there are reasons for considering the meanings of aconstructions grammatical meanings. Notably, Noël (2007b: 188) broaches grammatical roles - i.e. syntactic functions in his discussion, but does not connect them to the meaning pole of a-constructions.

41 Tomasello (2003: 173) states that there are so few studies of input frequency conditions that generalizations on the basis of individual high frequency cases cannot be excluded. However, it is at least tempting to hypothesize that generalizations seemingly based on individual cases might in reality reflect the important role of high-frequency cases at the start of the process rather than cast doubt on the role of type frequency.

${ }^{42}$ Cf. Rostila (2007: 149-150) for further discussion; this parallel is also drawn by Noël (2007a).
} 
The conditions prevailing among German PO-Ps speak for the same conclusion. The case of prospective auf demonstrates this perhaps most clearly, since it can be verified that the choice of $\mathrm{P}$ became fixed with warten at an earlier point (Hundt 2001: 182), while present-day data like (2), (6bd) and (7) testify to the existence of a productive pattern. In other words, warten + auf formed a verb island that has been generalized to an a-construction. Moreover, synchronic variation among German PO-Ps also suggests a parallel to generalization in child language: the bulk of PO-Ps seem to form verb islands in that the choice of PO-P is non-generalizable, and the simultaneous presence of more or less productive patterns suggests that some of the idiosyncratic patterns tend to be generalized. Assuming the credo of grammaticalization research that synchronic variation reflects diachronic change (Lehmann 1985), these conditions also hint at parallels between ontogeny and phylogeny. After clarifying some principal issues regarding such parallels, I will turn to the question of how their validity could be established on the basis of studying the diachrony of German PO-Ps.

One might doubt parallels between processes of child language and diachronic processes on grounds that child language might not be the locus of innovation. Children might not have the social standing required to ensure the successful propagation of innovations; moreover, studies of child language suggest that children are rather conservative learners, tending to imitate rather than innovate (Tomasello 2003: 176; 194; 2006). However, central tenets of CxG make it seem unnecessary to differentiate between children and adults in the study of historical processes - at least on the level granularity mostly attainable in such studies. If languages are indeed learned on the basis of domaingeneral cognitive abilities (Goldberg 2003: 222) that adults also still possess (see Rostila 2012: 216$217 ; 220-224$ for discussion), it stands to reason that adult generalization processes are essentially the same as those of children. ${ }^{43}$ Thus findings of research into generalization in child language would seem to be a legitimate source of working hypotheses for diachronic corpus studies of the emergence of a-constructions. In the following, I will outline a research agenda for such a study of German productive PO-Ps, concentrating on the case of prospective auf.

Productive PO-Ps would seem to constitute a particularly fruitful object of research for a study exploiting insights into child language generalization regarding argument structure and aimed at verifying parallels between ontogeny and phylogeny. After all, the point of departure of their development (lexically selected PO-Ps) and its outcome (productive PO-Ps) parallel the way stations of child language generalization: verb islands and a-constructions, respectively. What, then, should be sought in corpora in order to verify whether e.g. the emergence of prospective auf has proceeded parallel to child language generalization? In practice, all cases where prospective predicates occur with auf would be relevant, but especially the following kinds of findings would point to parallels to ontogeny:

- coexistence of several prospective predicates selecting auf before the spread of auf to further such predicates would point to the role of type variation

- $\quad$ high frequency of particular prospective predicates (e.g. warten) with auf before the spread of auf to further prospective predicates would hint at the role of high-frequency items as points of reference; if other prospective predicate + auf combinations were virtually absent at the same time, this would hint at analogical extension on the basis of individual cases

\footnotetext{
${ }^{43}$ Notably, also the usage-based model (e.g. Langacker 1987; Croft and Cruse 2004) suggests that children and adults generalize under the same conditions, i.e. on the basis of type variation, in that the model does not differentiate between between child learners and adult users.
} 
The period most fruitful for such studies would probably be late stages of Middle High German and the whole of Early High German (1350-1650), since especially the latter period was characterized by a spread of PO structures (cf. Korhonen 2006: 1466). Whether the existing corpora of these periods (e.g. Bonner Frühneuhochdeutschkorpus, 'Bonn corpus of Early High German') are large enough to enable the required frequency observations remains to be established.

\section{Outlook}

The proposal that there exists a class of productive/grammaticalized PO-Ps that can be described as a-constructions opens some at least partly new avenues of research. The most obvious of these is the search for productive PO-Ps (and case affixes with similar properties) in languages other than German and their description as a-constructions; cf. for instance wait/hope/prepare for and good/bad/skillful/talented at in English. Another one is the diachronic corpus study of the emergence of productive PO-Ps in different languages, perhaps along the lines sketched in 3.3.

The proposal also has consequences for the description of primary adpositions in general. It suggests that instead of a two-way classification into lexical vs. non-lexical/functional/grammatical adpositions (cf. Rauh 1993; Tseng 2001 for doubts regarding a two-way split), at least a three-way division is needed: primary lexical adpositions vs. lexically selected PO-Ps vs. productive PO-Ps, which form a-constructions. ${ }^{44}$ In the following, I will outline this proposal and relate it to the grammaticalization scenario discussed in 3.1.

Figure 2 shows the types of primary adpositions my proposal implies (numbers 1-4). The block arrows in it indicate the grammaticalization cline of a-constructions envisaged by me, from which certain types of primary adpositions emerge. ${ }^{45}$

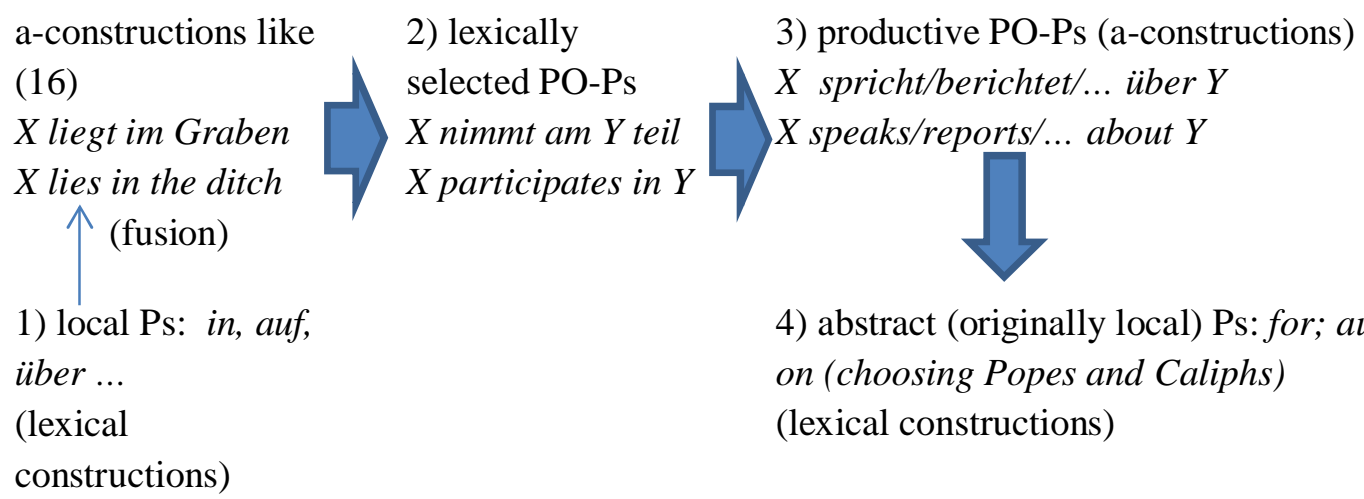

Figure 2: Types of primary adpositions and their grammaticalization cline

The first type of primary adpositions is that of local lexical adpositions. Such adpositions head the complements of verbs of motion and position like go, lie, be, and adjuncts of location. Both these structures emerge when adpositions of type 1 are inserted into a-constructions of the type presented in (16). ${ }^{46}$ If such an a-construction is entrenched with a certain verb or other predicate and a certain

\footnotetext{
44 The latter two groups correspond to Rauh's (1993) case prepositions.

${ }^{45}$ I do not assume that the different types form discrete categories, but constitute points on a continuum.

${ }^{46} \mathrm{Cf}$. note 13 for a-constructions as a source of adjuncts.
} 
adposition of type 1 (cf. stage 2 of the grammaticalization scenario in 3.1), this gives rise to lexically selected PO-Ps. Notably, these adpositions are no longer lexical constructions, but parts of a larger lexical construction. Next, as argued in this paper, lexically selected PO-Ps may be "prised" out of such constructions, i.e. be reanalyzed as signs in their own right, with meaning components taken over from verbs and other predicates they have been lexicalized with. The result is type 3 of primary adpositions, which in reality consists of a-constructions in the guise of PO-Ps - again a type of adpositions not reducible to lexical constructions.

Finally, type 4 is meant to capture primary adpositions with abstract meanings truly capable of self-licensing (cf. 2.1), i.e. senses specialized for adjunct use. ${ }^{47}$ The source of this type might be a reanalysis resembling the emergence of productive PO-Ps: adpositions might be extracted out of aconstructions on PO-Ps and become lexical constructions again. It is doubtful whether such a process actually takes place, since it is easy to think of possible cases in point like the title/topic uses of über, on and about (cf. (10b) above and e.g. On choosing Popes and Caliphs ${ }^{48}$; about your resignation) as instances of a-constructions on PO-Ps (= type 3) able to appear without a verb in certain genres. Adpositions of type 4 may virtually only appear in fixed phrases like auf Zeit, auf jeden Fall, for and against, which might go back to a-constructions used frequently enough to entrench them with particular words. ${ }^{49}$ Such phrases can sometimes function as a model, however, and this may in effect mean the rise of type 4 adpositions, cf. hypothetically auf Zeit 'for a time' $\rightarrow$ auf absehbare Zeit 'for the foreseeable future', auf Dauer 'in the long run', etc. It might also be useful to relate the development of Ps like for and um occurring in structures like I prefer for you to know it and um zu ... 'in order to' to this scenario.

\section{Source references of authentic examples}

(2c): www.pummeldex.de/, accessed: March 2, 2006.

(2d): www.faz.net/aktuell/wissen/mensch-gene/training-fuer-senioren-denksport-macht-neugierig-auf-mehr11633105.html (title), accessed: May 11, 2013)

(2e): Schröter, p. 203. (See below section Sources for the origin of examples drawn from literary works.)

(6c): www.spiegel.de/auto/aktuell/0,1518,650453,00.html, accessed: September 22, 2009.

(6d): Olivier, p. 483.

(7a): www.spiegel.de/sport/fussball/em-2012-gastgeber-ukraine-droht-in-der-gruppenphase-zu-scheitern-a837698.html (title), accessed June 12, 2012.

(7b): www.spiegel.de/ (title), accessed: June 3, 2009.

(7c): www.spiegel.de/kultur/musik/0,1518,748296,00.html, accessed: March 1, 2011.

(7d): www.spiegel.de/karriere/berufsstart/dieter-lenzen-fordert-master-abschluss-fuer-alle-a-834469.html, accessed: May 22, 2012.

(7e): www.spiegel.de/politik/ausland/us-vizepraesident-joe-biden-empfiehlt-schrotflinten-a-884415.html, accessed February 20, 2013.

(8a): Kunkel, p. 533.

(8b): www.spiegel.de/ (title), accessed: December 16, 2010.

\footnotetext{
${ }^{47}$ Temporal adpositions like those in am Montag/on Monday and in der Nacht/in the night probably form the core of this class, but hardly emerge from a development involving the stages represented by types 2 and 3. They rather result from the direct extension of local adpositions to relations of time.

${ }^{48}$ www.tribune.com.pk/story/524854/on-choosing-popes-and-caliphs/, accessed: May 22, 2013.

${ }^{49}$ Rostila (2013), an attempt to analyze both verb complements and adjuncts as going back to the same a-construction, would also preclude this type of prepositions as independent lexical constructions.
} 
(8f): www.vonwolkenstein.de/ wolkenstein-forum/showthread.php?t=893, accessed: May 11, 2006.

(8h): www.spiegel.de/reise/aktuell/0,1518,771125,00.html, accessed: June 28, 2011.

(10b): www.woche.de/titelthema2.htm, accessed: September 25, 2001.

(11a): www.spiegel.de/politik/ausland/ex-aussenminister-david-miliband-fordert-mehr-grossbritannien-inder-eu-a-881912.html, accessed: May 22, 2013.

(11b): www.spiegel.de/gesundheit/ernaehrung/sport-mit-guter-leistung-dank-rohkost-profi-erklaerternaehrungskonzept-a-882002.html, accessed: May 22, 2013.

(11c): www.wohnenaufzeit24.de, accessed: February 20, 2013.

(12d): www.faz.net/aktuell/feuilleton/diskussion-um-gendiagnostik-so-werden-moralische-konflikte-

kleingekocht-12168895.html (title), accessed: May 12, 2013.

(12e): www.stern.de/wirtschaft/arbeit-karriere/arbeit/bezahlung-die-debatte-um-den-mindestlohn-

604845.html (title), accessed: May 12, 2013.

(13c): www.spiegel.de/, accessed: June 30, 2011.

(14b): www.derstandard.at/1250598, accessed: May 12, 2013.

\section{Sources}

Danella, Utta: Nina. Wilhelm Heyne Verlag, Munich 1992.

DUWB: Duden Deutsches Universalwörterbuch. 7. edition. Dudenverlag, Mannheim/Zurich 2011.

Kunkel, Thor: Endstufe. Eichborn, Berlin 2004.

Olivier, Stefan: Jedem das Seine. Nannen-Verlag, Hamburg 1961.

Schröter, Heinz: Stalingrad. Bis zur letzten Patrone. Cinema-Verlag, Waiblingen 1961.

\section{References}

Askedal, John Ole. 2006. Regrammatikalisierung. Begriffliche Überlegungen und zwei deutsche Beispiele. In Ulrich Breuer \& Irma Hyvärinen (eds.). Wörter - Verbindungen. Festschrift für Jarmo Korhonen zum 60. Geburtstag, 301-316. Frankfurt/M: Peter Lang.

Avrahami, Judith, Yaakov Kareev, Yonatan Bogot, Ruth Caspi, Salomka Dunaevsky \& Sharon Lerner. 1997. Teaching by examples: Implications for the process of category acquisition. The Quarterly Journal of Experimental Psychology 50A(3), 586-606.

Bierwisch, Manfred. 1988. On the grammar of local prepositions. In Manfred Bierwisch, Wolfgang Motsch \& Ilse Zimmermann (eds.), Syntax, Semantik und Lexikon, 11-66. Berlin: AkademieVerlag.

Boas, Hans C. 2003. A constructional approach to resultatives. Stanford: CSLI Publications.

Boas, Hans C. 2011. Coercion and leaking argument structures in Construction Grammar. Linguistics 49.6, 1271-1303.

Boas, Hans C. 2014. Lexical and phrasal approaches to argument structure: Two sides of the same coin. Theoretical Linguistics 40(1-2), 89-112.

Breindl, Eva. 1989. Präpositionalobjekte und Präpositionalobjektsätze im Deutschen. Tübingen: Niemeyer.

Brinton, Laurel J. \& Elizabeth Closs Traugott. 2005. Lexicalization and language change. Cambridge: Cambridge University Press.

Bybee, Joan. 2003. Mechanisms of change in grammaticization: the role of frequency. In Brian Joseph and Richard D. Janda (eds.), The Handbook of Historical Linguistics, 602-623. Oxford: Blackwell.

Bybee, Joan. 2006. From usage to grammar: the mind's response to repetition. Language 82, 711733.

Chomsky, Noam. 1986. Knowledge of language. Its nature, origin, and use. New York: Praeger. 
Croft, William. 2000. Explaining language change: an evolutionary approach. Harlow: Longman.

Croft, William \& D. Alan Cruse. 2004. Cognitive Linguistics. Cambridge: Cambridge University Press.

Detges, Ulrich \& Richard Waltereit. 2002. Grammaticalization vs. reanalysis: a semantic-pragmatic account of functional change in grammar. Zeitschrift für Sprachwissenschaft 21, 151-195

Duden. 1984. Grammatik der deutschen Gegenwartssprache. (4. edn.). Mannheim, Vienna \& Zurich: Dudenverlag.

Dürscheid, Christa. 1999. Die verbalen Kasus des Deutschen. Untersuchungen zur Syntax, Semantik und Perspektive. Berlin \& New York: Walter de Gruyter.

Engelberg, Stefan. 2009. Blätter knistern über den Beton. Zwischenbericht aus einer korpuslinguistischen Studie zur Bewegungsinterpretation bei Geräuschverben. In Edeltraud Winkler (ed.). Konstruktionelle Varianz bei Verben. (OPAL Sonderheft 4/2009), 75-97. Mannheim: Institut für Deutsche Sprache.

Felfe, Marc. 2012. Das System der Partikelverben mit „an“. Eine konstruktionsgrammatische Untersuchung. Berlin \& New York: Walter de Gruyter.

Fillmore, Charles J. \& Sue Atkins. 2000. Describing polysemy: the case of crawl. In Yael Ravin \& Claudia Leacock (eds.), Polysemy: Linguistic and computational approaches, 91-110. Oxford: Oxford University Press.

Fried, Mirjam. 2009. Construction Grammar as a tool for diachronic analysis. Constructions and Frames 1, 262-291.

Givón, Talmy. 2002. Bio-linguistics: the Santa Barbara lectures. Amsterdam \& Philadelphia: John Benjamins.

Goldberg, Adele E. 1995. Constructions. A Construction Grammar approach to argument structure. Chicago \& London: University of Chicago Press.

Goldberg, Adele E. 2003. Constructions: a new theoretical approach to language. Trends in Cognitive Sciences 7.5, 219-224.

Goldberg, Adele E. 2006. Constructions at work. The nature of generalization in language. Oxford: Oxford University Press.

Goldberg, Adele E., Devin Casenhiser \& Tiffani R. White. 2007. Constructions as categories of language. New Ideas in Psychology 25, 70-86.

Helbig, Gerhard. 1973. Die Funktionen der substantivischen Kasus in der deutschen Gegenwartssprache. Halle, Saale: VEB Max Niemeyer Verlag.

Hundt, Markus. 2001. Grammatikalisierungsphänomene bei Präpositionalobjekten in der deutschen Sprache. Zeitschrift für germanistische Linguistik 29, 167-191.

Israel, Michael. 1996. The way constructions grow. In Adele E. Goldberg (ed.), Conceptual structure, discourse and language, 217-230. Stanford: CSLI Publications.

Kay, Paul. 2005. Argument structure constructions and the argument-adjunct distinction. In Mirjam Fried \& Hans C. Boas (eds.) Grammatical constructions: Back to the Roots, 71-98. Amsterdam \& Philadelphia: John Benjamins

Knobloch, Clemens. 2009. Noch einmal: Partikelkonstruktionen. Zeitschrift für germanistische Linguistik 37, 544-564.

Kolehmainen, Leena. 2010. From a spatial adposition to a grammatical relations' marker: Contactand context-induced grammaticalization and their interaction. Lähivõrdlusi/Lähivertailuja 20, 98-154.

Korhonen, Jarmo. 2006. Valenzwandel am Beispiel des Deutschen. In Vilmos Ágel, Ludwig M. Aichinger \& Hans-Werner Eroms (eds.) Dependenz und Valenz. Ein internationales Handbuch der zeitgenössischen Forschung, 1462-1474. Berlin \& New York: Walter de Gruyter. 
Langacker, Ronald W. 1987. Foundations of Cognitive Grammar. Vol. I.: Theoretical prerequisites. Stanford: Stanford University Press.

Lass, Roger. 1997. Historical linguistics and language change. Cambridge: Cambridge University Press.

Lehmann, Christian. 1985. Grammaticalization: synchronic variation and diachronic change. Lingua e stile 20, 303-318.

Lehmann, Christian. 2002. New reflections on grammaticalization and lexicalization“. In Ilse Wischer \& Gabriele Diewald (eds.), New reflections on grammaticalization, 1-18. Amsterdam \& Philadelphia: John Benjamins.

Lerot, Jacques. 1982. Die verbregierten Präpositionen in Präpositionalobjekten. In Werner Abraham (ed.), Satzglieder im Deutschen: Vorschläge zur syntaktischen, semantischen und pragmatischen Fundierung, 261-291. Tübingen: Narr.

Michaelis, Laura A. 2004. Type shifting in Construction Grammar: An integrated approach to aspectual coercion. Cognitive Linguistics 15, 1-67.

Mithun, Marianne. 2002. An invisible hand at the root of causation: the role of lexicalization in the grammaticalization of causatives. In Ilse Wischer \& Gabriele Diewald (eds.), New Reflections on Grammaticalization, 237-258. Amsterdam \& Philadelphia: John Benjamins.

Müller, Stefan. 2006. Phrasal or lexical constructions?“ Language 82(4), 850-883.

Müller, Stefan \& Stephen M. Wechsler. 2014. Lexical approaches to argument structure. Theoretical Linguistics 40(1-2), 1-76.

Noël, Dirk. 2007a. Verb valency patterns, constructions and grammaticalization. In Thomas Herbst \& Katrin Götz-Votteler (eds.). Valency: Theoretical, Descriptive and Cognitive Issues, 6783. Berlin \& New York: Mouton de Gruyter.

Noël, Dirk. 2007b. Diachronic construction grammar and grammaticalization theory. Functions of Language 14, 177-202.

Nunberg, Geoffrey, Ivan A. Sag \& Thomas Wasow. 1994. Idioms. Language 70, 491-538.

Olsen, Susan. 1997. Prädikative Argumente syntaktischer und lexikalischer Köpfe: Zum Status der Partikelverben im Deutschen und Englischen. Folia Linguistica 31(3-4), 301-329.

Oppenrieder, Wilhelm. 1991. Von Subjekten, Sätzen und Subjektsätzen. Untersuchungen zur Syntax des Deutschen. Tübingen: Niemeyer.

Östman, Jan-Ola. 2005. Construction discourse: a prolegomenon. In Jan-Ola Östman \& Mirjam Fried (eds.) Construction Grammars: Cognitive grounding and theoretical extensions, 121-143. Amsterdam \& Philadelphia: John Benjamins.

Price, Glanville. 1997. Negative particles in French. In Stewart Gregory \& D.A. Trotter (eds.), De mot en mot: Aspects of medieval linguistics. Essays in honour of William Rothwell, 173-190. Cardiff: University of Wales Press.

Rauh, Gisa. 1993. On the grammar of lexical and non-lexical prepositions in English. In Cornelia Zelinsky-Wibbelt (ed.), The semantics of prepositions: from mental processing to natural language processing, 99-150. Berlin \& New York: Mouton de Gruyter.

Rostila, Jouni. 2002. Die Präpositionen der Präpositionalobjekte als ein Kongruenzphänomen.

In Mariann Skog-Södersved, Christoph Parry and Brigitte von Witzleben (eds.), Grenzüberschreibungen. Festschrift für Henrik Nikula zu seinem 60. Geburtstag, 129-139. Vaasa \& Germersheim: SAXA.

Rostila, Jouni. 2004. Towards a construction approach to grammaticalization in prepositional objects. In Marja Nenonen (ed.), Papers from the 30 ${ }^{\text {th }}$ Finnish Conference of Linguistics, 192-200. Joensuu: University of Joensuu.

Rostila, Jouni. 2005. Zur Grammatikalisierung bei Präpositionalobjekten. In Torsten Leuschner, Tanja Mortelmans \& Sarah De Groodt (eds.), Grammatikalisierung im Deutschen, 135-166. Berlin \& New York: Walter de Gruyter. 
Rostila, Jouni. 2006a. Construction Grammar as a functionalist generative grammar. In Piotr P. Chruszczewski, Michał Garcarz \& Tomasz P. Górski (eds.), At the crossroads of linguistics sciences, 365-376. Cracow: Tertium.

Rostila, Jouni. 2006b. Storage as a way to grammaticalization. Constructions 1/2006. http://www.elanguage.net/journals/index.php/constructions/issue/view/16 (accessed 2 December 2014).

Rostila, Jouni. 2007. Konstruktionsansätze zur Argumentmarkierung im Deutschen. Tampere: Tampere University Press (available at: http://urn.fi/urn:isbn:978-951-44-7085-1).

Rostila, Jouni. 2012. Konstruktionsgrammatik: innovative Wege für den DaF-Unterricht, insbesondere den Grammatikunterricht?" German as a Foreign Language 2-3/2012, 215 237.

http://www.gfl-journal.de/2-2012/Rostila.pdf (accessed 2 December 2014).

Rostila, Jouni. 2013. Konstruktioista, komplementeista ja adjunkteista [On constructions, complements and adjuncts]. Paper presented at the Annual Finnish Conference of Linguistics, University of Tampere, 4-5 May.

Rostila, Jouni. 2014. Inventarisierung als Grammatikalisierung: produktive Präpositionalobjekte und andere grammatikalisierte Linking-Muster. In Alexander Lasch \& Alexander Ziem (eds.), Grammatik als Netzwerk von Konstruktionen: Sprachwissen im Fokus der Konstruktionsgrammatik, 97-116. Berlin: Walter de Gruyter.

Rothstein, Susan D. 2001. Predicates and their subjects. Dordrecht: Kluwer.

Ruppenhofer, Josef \& Laura A. Michaelis. 2010. A constructional account of genre-based argument omissions. Constructions and Frames 2.2, 158-184.

Schøsler, Lene. 2007. The status of valency patterns. In Thomas Herbst \& Katrin Götz-Votteler (eds.), Valency: Theoretical, descriptive and cognitive issues, 51-65. Berlin \& New York: Mouton de Gruyter.

Stefanowitsch, Anatol. 2007. Konstruktionsgrammatik und Korpuslinguistik. In Kerstin Fischer \& Anatol Stefanowitsch (eds.), Konstruktionsgrammatik: Von der Anwendung zur Theorie, 151176. Tübingen: Stauffenburg.

Stefanowitsch, Anatol. 2008. R-Relationen im Sprachvergleich: die Direkte-Rede-Konstruktion im Englischen und Deutschen. In Anatol Stefanowitsch \& Kerstin Fischer (eds.), Konstruktionsgrammatik II: Von der Konstruktion zur Grammatik, 247-261. Tübingen: Stauffenburg.

Tomasello, Michael. 2003. Constructing a language. A usage-based theory of language acquisition. Cambridge, Mass. \& London: Harvard University Press.

Tomasello, Michael. 2006. Construction Grammar for kids. Constructions SV1-11/2006. http://elanguage.net/journals/constructions/article/view/26 (accessed 2 December 2014).

Tseng, Jesse. 2001. Rethinking lexical and functional prepositions. In Ljiljana Šarić \& Donald F. Reindl (eds.), On prepositions, 283-327. Oldenburg: BIS.

Welke, Klaus. 1988. Einführung in die Valenz- und Kasustheorie. Leipzig: VEB Bibliographisches Institut.

Welke, Klaus. 1994. Thematische Relationen. Sind thematische Relationen semantisch, syntaktisch oder/und pragmatisch zu definieren? Deutsche Sprache 22.1, 1-18.

Welke, Klaus. 2002. Deutsche Syntax funktional. Perspektiviertheit syntaktischer Strukturen. Tübingen: Stauffenburg.

Welke, Klaus. 2009. Konstruktionsvererbung, Valenzvererbung und die Reichweite von Konstruktionen. Zeitschrift für germanistische Linguistik 37, 514-543.

Welke, Klaus. 2011. Valenzgrammatik des Deutschen: Eine Einführung. Berlin \& New York: Walter de Gruyter.

Zifonun, Gisela, Ludger Hoffmann, Bruno Strecker \& Joachim Ballweg. 1997. Grammatik der deutschen Sprache. Berlin \& New York: Walter de Gruyter. 
